\title{
Is there a place for cholangioscopic evaluation of biliary anastomotic stricture after deceased donor liver transplant?
}

\author{
Fernanda Prata MARTINS, Silvia Mansur Reimão SELETI, Mônica Lucia CONTINI, \\ Gustavo Andrade DE PAULO and Angelo Paulo FERRARI
}

Received: 14 September 2019 Accepted: 31 July 2020

\begin{abstract}
Background - Biliary complications remain one of the most important causes of morbidity and graft loss after liver transplant (LT). Endoscopic therapy of biliary complications has proven to be effective over time, leaving surgical treatment restricted to only very few cases. However, we cannot yet predict which patients will have the greatest potential to benefit from endoscopic treatment. Objective-On this premise we decide to conduct this study to evaluate the role and safety of single operator cholangioscopy (SOC) in the endoscopic treatment of post-LT biliary anastomotic strictures (AS). Methods - Between March/2016 and June/2017, 20 consecutive patients referred for endoscopic treatment for biliary anastomotic stricture were included in this prospective observational cohort study. Inclusion criteria were age over 18 years old, and a deceased LT performed within at least 30 days. Exclusion criteria were non-anastomotic biliary stricture, biliary leakage, cast syndrome, any previous endoscopic therapy, pregnancy and inability to provide informed consent. All patients underwent SOC before endoscopic therapy with fully covered self-expandable metal stent (FCSEMS) and after stent removal. Results - At pre-treatment SOC, stricture orifice and fibrotic changes could be visualized in all patients, vascular changes and surgical sutures in $60 \%$ and acute inflammatory changes in 30\%. SOC was essential for guidewire placement in five cases. FCSEMS was successfully deployed in all patients. Stricture resolution rate was $44.4 \%$ (median stent indwelling 372 days). Stricture recurrence was $12.5 \%$ (median follow-up of 543 days). Adverse events were distal (66.6\%) and proximal (5.5\%) stent migration, stent occlusion (16.6\%), severe abdominal pain (10\%) and mild acute pancreatitis $(10 \%)$. SOC was repeated after FCSEMS removal. Post-treatment SOC showed fibrotic changes in all but one patient; vascular and acute inflammatory changes were less frequent in comparison to index procedure. The disappearance of suture material was remarkable. None of the cholangioscopic findings were statistically correlated to treatment outcome or stricture recurrence. Conclusion-Endoscopic retrograde cholangiography with SOC is feasible in post-LT patients with AS. Cholangioscopic findings can be classified into fibrotic, vascular and acute inflammatory changes. Cholangioscopy may be helpful to assist guidewire passage, but Its overall role for changing management is post-LT patients was not demonstrated.

HEADINGS - Liver transplant. Self expandable metallic stents. Pathologic constriction. Biliary tract.
\end{abstract}

\section{INTRODUCTION}

Liver transplant is the final treatment option for end stage liver disease. In 2018, 2,182 liver transplants were performed in Brazil (10.5/million inhabitants) second only to the United States in absolute numbers ${ }^{(1)}$. Despite improvements in surgical technique, graft preservation and immunosuppressive drugs, biliary complications remain an important cause of morbidity, graft loss and mortality. Biliary anastomotic strictures (AS) may affect $12 \%$ to $20 \%$ of patients after a deceased liver transplantation (DLT) and up to $40 \%$ after living donor liver transplantation (LDLT) ${ }^{(2)}$.

Endoscopic therapy is definitely the first line modality for patients with duct-to-duct anastomosis, reaching $80 \%$ up to $100 \%$ success rate ${ }^{(2)}$. However, endoscopic retrograde cholangiography (ERCP) does not allow direct visualization of neither the bile duct nor the stricture itself. Direct visualization of the bile duct was firstly described in $1976^{(3)}$ using a mother-baby scope. Regardless of an initial excitement, it failed to become a standard procedure due to the fragility of the baby scope and the need of two operators, ultimately leading to elevated cost. The introduction of a single operator cholangioscopy (SOC) set using the SpyGlass direct visualization system (Boston Scientific Corporation, Natick, MA, USA) has defeated most of these limitations ${ }^{(4)}$. Since 2015 it was upgraded to a digital system (SpyGlass ${ }^{\mathrm{TM}}$ DS, Boston Scientific, Marlborough, MA, USA) with higher resolution image quality and $60 \%$ wider field of view ${ }^{(5)}$.

To date, SOC has been used mostly to evaluate indeterminate biliary strictures and treat difficult bile duct stones ${ }^{(6-9)}$. There is limited data about the role of direct cholangioscopy in post liver transplant biliary complications. There have been some case reports $^{(10-14)}$, case series ${ }^{(15-18)}$ and two small prospective studies on post liver transplant biliary complications, one with the first generation SpyGlass $^{(19)}$ and one with SpyGlass ${ }^{\mathrm{TM}} \mathrm{DS}^{(20)}$. To our best knowledge there is no published data on direct cholangioscopy performed both before and after endoscopic therapy of post-LT biliary anastomotic strictures. Therefore, the aim of this study was to investigate the role and safety of SOC during endoscopic treatment of post-LT biliary anastomotic strictures.

Declared conflict of interest of all authors: De Paulo GA and Ferrari AP are independent consultants for Boston Scientific Brazil.

Disclosure of funding: no funding received

Hospital Israelita Albert Einstein, São Paulo, SP Brasil.

Corresponding author: Fernanda Prata Martins. E-mail: fernandapbm@gmail.com 


\section{METHODS}

This is a prospective observational cohort study conducted at Hospital Israelita Albert Einstein (HIAE), a private tertiary center in São Paulo, Brazil. Our hospital has Joint Commission International accreditation, being one of largest transplant centers in South America.

The Research Ethics Committee approved the study and it was conducted in accordance with the ethical standards of the Helsinki Declaration issued by the World Medical Association. Informed consent was obtained before ERCP for all patients. There was no industry funding or grant for the current study. The study is registered at ClinicalTrials.gov and the registration number is NCT02543151.

\section{Patients}

Between March 2016 and June 2017, all consecutive patients with suspected post DLT biliary complications referred to ERCP were assessed for eligibility in the study. Inclusion criteria were patients over 18 years old with a biliary anastomotic stricture referred for endoscopic treatment. Exclusion criteria were nonanastomotic biliary stricture, biliary leakage, cast syndrome, liver transplantation within the past 30 days, any previous endoscopic therapy, pregnancy and inability to provide informed consent.

All patients were asked to provide written informed consent before the index ERCP. Patients with any exclusion criteria or a normal cholangiogram were removed from the study and are shown as excluded patients on the flowchart (FIGURE 1).

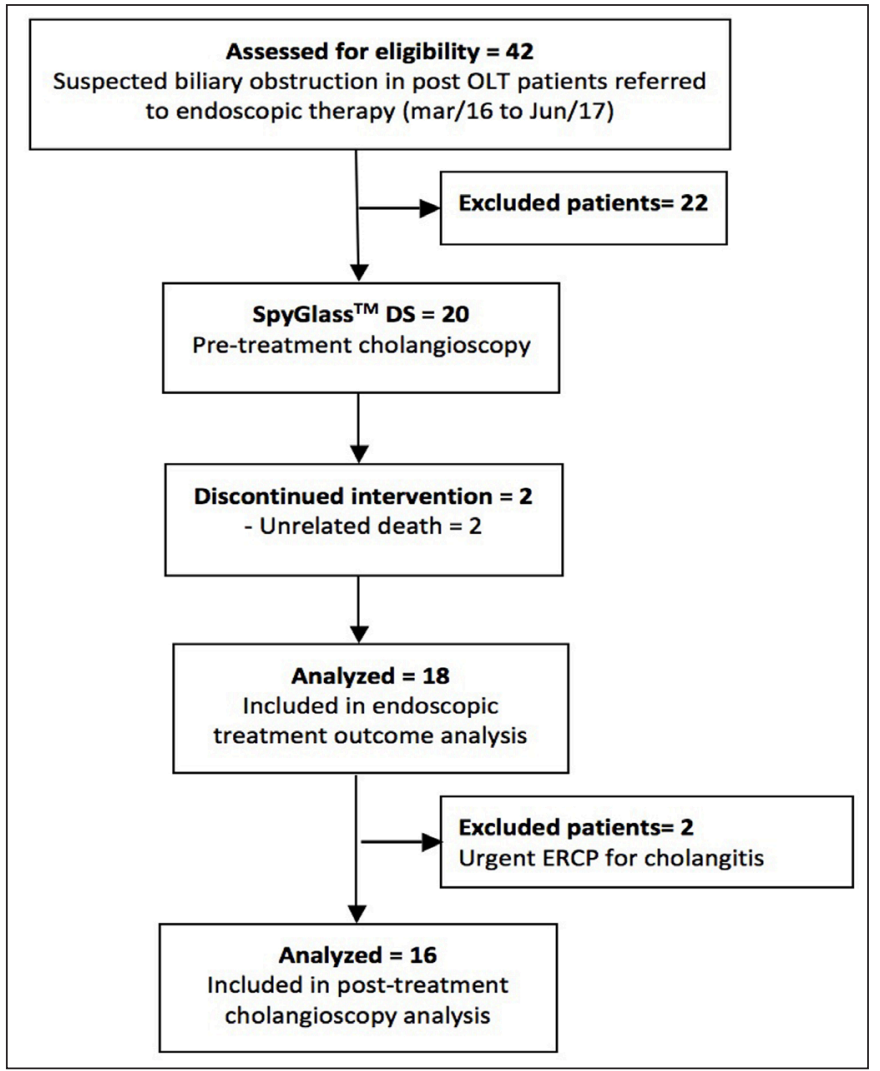

FIGURE 1. Flow chart of patients.

OLT: orthotopic liver transplant; ERCP: endoscopic retrograde cholangiography.

\section{Procedures}

All ERCPs were performed with therapeutic videoduodenoscopes (TJF180, TJF160, or TJF140, Olympus Optical Co, Ltd, Tokyo, Japan) and patients received monitored anesthesia care. The procedure was planned to be performed on an outpatient basis and hospitalization was reserved for exceptional cases.

Biliary anastomotic stricture was defined as a thin, short and localized narrowing in the area of biliary anastomosis ${ }^{(2)}$. After it was detected by a cholangiogram and the eligibility was finally confirmed, a guide wire was used for deep cannulation and an sphincterotomy was performed in all patients. No balloon dilation of the papilla was performed. The single operator cholangioscope (SpyScope ${ }^{\mathrm{TM}}$ DS) was pushed over the guide wire through the duodenoscope's working channel into the bile duct.

If the guide wire had been placed above the anastomotic stricture, the SpyScope ${ }^{\mathrm{TM}}$ DS would be advanced up to the hepatic hilum to fulfill a complete evaluation of the donor's bile duct. Although, if the stricture had not been traversed under fluoroscopic guidance, the SpyScope ${ }^{\mathrm{TM}}$ DS should be used not only to evaluate the bile duct but also to achieve guide wire passage across the AS under direct visual guidance ${ }^{(18)}$. The procedure was considered successful if the cholangioscope was advanced into the bile duct accomplishing adequate AS visualization and guide wire placement. If the guide wire could be passed through the AS, but it was too tight to allow introduction of the cholangioscope, evaluation was performed only from the distal end. We did not perform dilatation in order to avoid reshaping the stricture features and minimize stent migration.

There is no standardization for cholangioscopic findings in benign biliary strictures. Based on published data ${ }^{(8,10,19)}$ we preestablished the nomenclature to be used in the study at the time it was designed. Cholangioscopy was intended to evaluate the presence of AS characteristics, stones and biliary debris. The AS characteristics were classified into fibrotic changes (presence of a pale scar area, mucosal projections and convergence of folds), vascular changes (prominent small caliber vessels and/or enlarged vessels), acute inflammatory changes (erosion and ulceration).

Once the cholangioscopic evaluation was finished, SpyScope ${ }^{\mathrm{TM}}$ DS was removed and all patients where treated with placement of a $60 \mathrm{~mm}$ x $10 \mathrm{~mm}$ fully covered self-expandable metal stent (WallFlex $^{\mathrm{TM}}$, Boston Scientific Corporation), unrelatedly to cholangioscopic findings. At this point, minimal dilation could be performed only if extremely needed to allow stent placement. Patients were discharged at the same day and a phone call follow-up was made within the next 24 hours.

Initially neither acute pancreatitis prophylaxis nor antibiotics were planned in the study trial. However, the protocol was revised after the tenth patient was included, due to the two cases of acute pancreatitis (patients 1 and 7). From this point, all patients received $100 \mathrm{mg}$ of rectal indomethacin immediately before and $1 \mathrm{~g}$ of Ceftriaxone 1 hour ahead of the procedure ${ }^{(21,22)}$.

Patients were evaluated every 3 months by a transplant team clinician with liver function tests and imaging examinations as required. Stent removal was scheduled at 12 months unless otherwise anticipated due to any clinical or laboratorial sign of migration or occlusion.

All metal stents were removed with a foreign body forceps, uneventfully. The stricture was considered resolved if there was no evidence of tight stenosis on fluoroscopy and if a $12 \mathrm{~mm}$ extraction balloon could easily be passed through the anastomosis. 
Once the fully covered self-expandable metal stent (FCSEMS) was removed, SpyGlass ${ }^{\mathrm{TM}}$ DS evaluation was repeated likewise the previous procedure.

Adverse events related to the procedure were defined and graded according to Cotton's classification ${ }^{(23)}$. Patients were followed for at least 1-year after metal stent removal or until death to assess stricture recurrence.

\section{Endpoints}

The primary endpoints were to describe mucosal characteristics of post-LT biliary anastomotic strictures and to assess a possible impact of cholangioscopic findings in predicting endoscopic treatment response.

The secondary endpoints were to evaluate bile duct mucosal aspect after endoscopic therapy with FCSEMS and procedure safety.

\section{Statistics}

Continuous variables were reported as means and standard deviation or as median and ranges in accordance with their homogeneity. Endoscopic treatment outcome was evaluated in a per protocol analysis. Categorical variables were compared by Fischer's exact test. A $P$-value $<0.05$ was considered to be statically significant. Statistical analysis was conducted by using GraphPad Prism 8 (San Diego, CA, USA).

\section{RESULTS}

Between March 2016 and June 2017, 42 consecutive patients were assessed for eligibility and 20 were included in the study (FIGURE1). All 20 patients had the initial cholangioscopy successfully performed and received a FCSEMS. Two of them died from unrelated causes before having the metal stent removed and the second cholangioscopy fulfilled and therefore lost follow-up. Detailed information is provided in FIGURE 1.

Baseline and demographic characteristics are summarized in TABLE 1. Median time elapsed between DLT and ERCP was 159.5 days (range 30 to 2488). All 20 patients had impaired liver tests, 95\% $(19 / 20)$ had dilated bile ducts and 5 had stones in the common bile duct at the abdominal ultrasound, though only 6 were symptomatic at the time they were referred for endoscopic therapy.

During ERCP, all patients underwent biliary sphincterotomy, but stricture dilation was performed with a CRE ${ }^{\mathrm{TM}}$ biliary dilatation balloon (Boston Scientific), only when strongly needed to place FCSEMS (4/20), and solely up to $6 \mathrm{~mm}$.

Despite the fact that the stricture orifice could be visualized in all patients at the first cholangioscopy, SpyScope ${ }^{\mathrm{TM}} \mathrm{DS}$ could only be passed through it in seven cases. Cholangioscopic aspects of AS were assessed according to the classification detailed above in this paper and are comprehensively presented in TABLE 2. A pale scar area (FIGURE 2) was seen in every patient, while vascular changes (FIGURE 3A) in 60\% (12/20) and acute inflammatory changes (FIGURE 3B) in 30\% (6/20) of them. An interesting finding was the presence of surgical sutures (FIGURE 4), visualized in 12 subjects $(60 \%)$. Although abdominal ultrasound had described stones in $5(25 \%)$ patients, only 1 was confirmed by cholangioscopy whereas 4 ended up being protruding suture material mixed with biliary debris. Cholangioscopy-assisted guide wire placement was necessary in $5(25 \%)$ cases.

All patients had a FCSEMS successfully deployed. The median metal stent indwelling in those who still had the stent in place at the time of removal was 372 (369-406) days. Stent removal was uneventful in all cases and stricture resolution was achieved in $44.4 \%$ $(8 / 18)$ in a per protocol analysis and $40 \%(8 / 20)$ in an intention to treat analysis. The patients who did not have the stricture resolved received either a second metal stent (6/10) or multiple plastic stents (4/10) at the endoscopist's discretion.

The stricture resolution after endoscopic re-treatment with a second metal stent was 66.7\% (4/6), and 50\% (2/4) after multiple plastic stent therapy.

Adverse events related to the procedure occurred in $4 / 20(20 \%)$ patients: $2 / 20(10 \%)$ had severe abdominal pain requiring hospitalization and 2/20 (10\%) had acute pancreatitis after FCSEMS placement. No adverse events were observed at stent removal. All adverse events were mild and treated conservatively. There were no deaths related to endoscopic treatment.

Among adverse events related to the metal stent itself, distal migration was by far the most common, affecting $66.6 \%$ of patients (12/18). Proximal migration occurred in 5.5\% (1/18) and occlusion in $16.6 \%(3 / 18)$ (TABLE 2). Nearly half of cases were asymptomatic and diagnosed only at scheduled ERCP for stent removal. FCSEMS migration was not correlated to stricture resolution $(P=0.6078)$. After a median follow-up of $543(233-1,000)$ days, stricture recurrence was observed in $12.5 \%$ of cases $(1 / 8)$. Stent migration was not associated to recurrence $(P>0.9999)$.

Two patients presented cholangitis as a consequence of stent occlusion and had the removal anticipated. They did not undergo cholangioscopy due to the high risk of worsening infection. The remaining 16 patients had a cholangioscopy realized after stent removal or migration. Fibrotic changes were seen in all but one

TABLE 1. Baseline characteristics of patients included in the study.

\begin{tabular}{lc}
\hline Variable & $\mathbf{N}$ \\
\hline $\mathrm{N}$ & 20 \\
Male:Female & $9: 11$ \\
Age (Years) & $50( \pm 14)$ \\
$\quad$ Mean $\left({ }_{ \pm}\right.$SD) & \\
Etiology & 6 \\
HCV & 5 \\
Alcohol & 9 \\
Other & $6(30 \%)$ \\
HCC & \\
MELD score & $29(18-39)$ \\
Median (range) & 6 h $( \pm 0.91)$ \\
Cold ischemia time (hours) & \\
Mean ( $\left.{ }^{\text {SD }}\right)$ & $0.77( \pm 0.27)$ \\
Warm ischemia time (hours) & $3(15 \%)$ \\
Mean ( ${ }_{ \pm}$SD) & $7(35 \%)$ \\
Hepatic artery thrombosis & \\
CMV infection & $411.5(657.2)$ \\
Time from OLT to ERCP & $159.5(30-488)$ \\
Mean ( $\left.{ }^{\text {SD }}\right)$ & \\
Median (range) & \\
\hline
\end{tabular}

HCV: hepatitis C virus; HCC: hepatocarcinoma; SD: standard deviation; MELD: model for end-stage liver disease; CMV: cytomegalovirus. 
TABLE 2. Cholangioscopic findings at the biliary anastomotic stricture before and after FCSEMS placement in each patient, and overall results of endoscopic treatment and follow up.

\begin{tabular}{|c|c|c|c|c|c|c|c|c|c|c|c|c|}
\hline \multirow[b]{2}{*}{ Patient } & \multirow[b]{2}{*}{$\begin{array}{l}\text { OLT to } \\
\text { ERCP } \\
\text { (days) }\end{array}$} & \multicolumn{4}{|c|}{ Pre-treatment cholangioscopy } & \multicolumn{4}{|c|}{ Post-treatment cholangioscopy } & \multirow[b]{2}{*}{$\begin{array}{l}\text { Stricture } \\
\text { resolu- } \\
\text { tion }\end{array}$} & \multirow[b]{2}{*}{$\begin{array}{c}\text { FCSEMS } \\
\text { adverse } \\
\text { event }\end{array}$} & \multirow[b]{2}{*}{$\begin{array}{l}\text { Stricture } \\
\text { recurrence }\end{array}$} \\
\hline & & $\begin{array}{l}\text { Fibrotic } \\
\text { changes }\end{array}$ & $\begin{array}{l}\text { Vascular } \\
\text { changes }\end{array}$ & $\begin{array}{l}\text { Acute in- } \\
\text { flammatory } \\
\text { changes }\end{array}$ & $\begin{array}{c}\text { Suture } \\
\text { material }\end{array}$ & $\begin{array}{l}\text { Fibrotic } \\
\text { changes }\end{array}$ & $\begin{array}{l}\text { Vascular } \\
\text { changes }\end{array}$ & $\begin{array}{l}\text { Acute in- } \\
\text { flammatory } \\
\text { changes }\end{array}$ & $\begin{array}{c}\text { Suture } \\
\text { material }\end{array}$ & & & \\
\hline 2 & 154 & Yes & Yes & Yes & Yes & Yes & Yes & Yes & No & No & Migration & $\mathrm{n} / \mathrm{a}$ \\
\hline 3 & 154 & Yes & Yes & Yes & Yes & Yes & No & No & No & No & Migration* & $\mathrm{n} / \mathrm{a}$ \\
\hline 4 & 40 & Yes & Yes & Yes & Yes & Yes & No & No & No & Yes & Migration* & No \\
\hline 7 & 215 & Yes & No & No & Yes & Yes & No & No & No & No & Migration* & $\mathrm{n} / \mathrm{a}$ \\
\hline 8 & 345 & Yes & Yes & No & No & Yes & Yes & No & No & Yes & Migration* & Yes \\
\hline 9 & 68 & Yes & Yes & No & Yes & $\mathrm{n} / \mathrm{a}^{\&}$ & $\mathrm{n} / \mathrm{a}$ & $\mathrm{n} / \mathrm{a}$ & $\mathrm{n} / \mathrm{a}$ & No & $\begin{array}{l}\text { Occlusion } \\
\text { Cholangitis }\end{array}$ & $\mathrm{n} / \mathrm{a}$ \\
\hline 10 & 260 & Yes & Yes & No & No & Yes & Yes & No & No & No & Migration* & $\mathrm{n} / \mathrm{a}$ \\
\hline 11 & 30 & Yes & Yes & No & Yes & Yes & No & No & No & Yes & No & No \\
\hline 15 & 360 & Yes & Yes & No & Yes & No & Yes & Yes & No & Yes & No & No \\
\hline 16 & 48 & Yes & No & No & Yes & $\mathrm{n} / \mathrm{a}$ & $\mathrm{n} / \mathrm{a}$ & $\mathrm{n} / \mathrm{a}$ & $\mathrm{n} / \mathrm{a}$ & Death & Unknown & $\mathrm{n} / \mathrm{a}$ \\
\hline 17 & 1968 & Yes & No & No & No & Yes & No & No & No & No & Migration* & $\mathrm{n} / \mathrm{a}$ \\
\hline 18 & 82 & Yes & Yes & No & Yes & Yes & Yes & No & No & No & Migration & $\mathrm{n} / \mathrm{a}$ \\
\hline 19 & 38 & Yes & Yes & No & Yes & Yes & No & No & No & No & $\begin{array}{l}\text { Migration } \\
\text { Occlusion }\end{array}$ & $\mathrm{n} / \mathrm{a}$ \\
\hline 20 & 2488 & Yes & Yes & No & No & Yes & No & No & No & Yes & No & No \\
\hline
\end{tabular}

OLT: orthotopic liver transplant; ERCP: endoscopic retrograde cholangiography; FCSEMS: self-expandable metal stent. n/a: not applicable. *Asymptomatic migration. ${ }^{*}$ Cholangioscopy was not performed due to cholangitis.

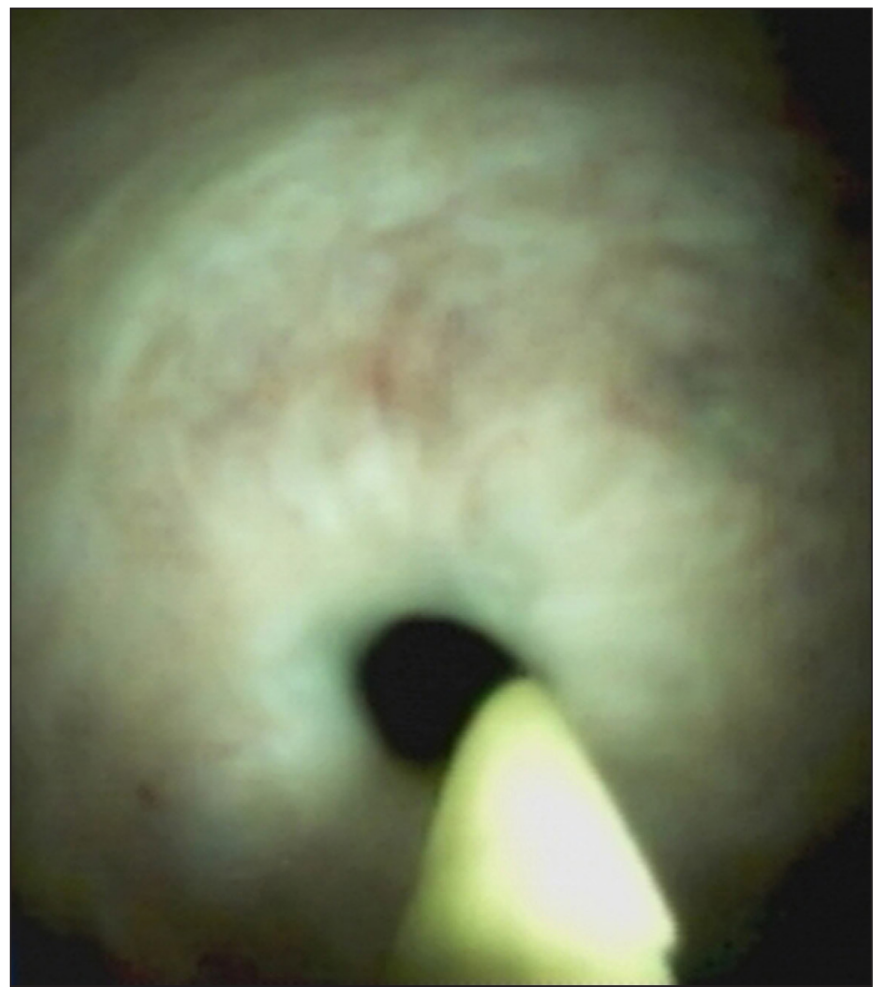

FIGURE 2. Cholangioscopy displayed a pale scar area, punctate stricture orifice and convergence of folds.

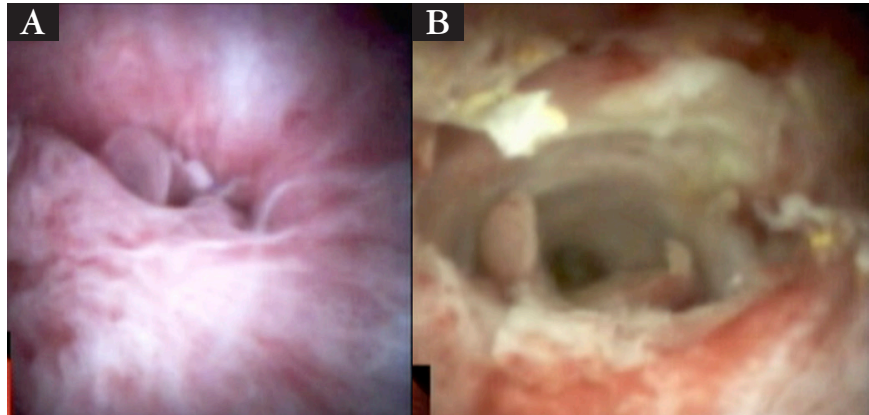

FIGURE 3. A pale scar area with prominent small caliber vessels $(\mathrm{A})$ and acute inflammatory changes $(\mathbf{B})$ - erosions - seen at biliary AS during direct cholangioscopy.

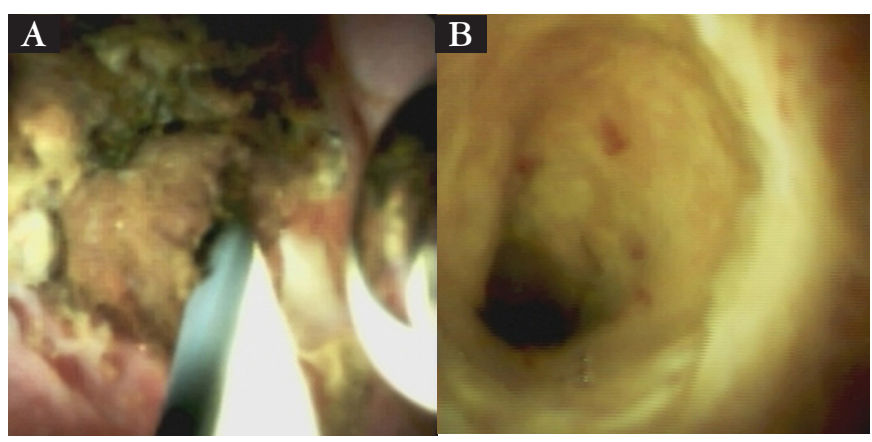

FIGURE 4. Cholangioscopy revealed a pale scar area with surgical sutures and biliary debris at biliary AS (A). After CSEMS removal, sutures were no longer visualized (B). 
patient (15/16); meanwhile vascular (6/16) and acute inflammatory changes (3/16) were less frequent when compared to the index procedure (FIGURE 5). The most remarkable finding of cholangioscopic evaluation at this point was the disappearance of suture material (FIGURE 3) in all patients. At removal cholangioscopy the SpyScope ${ }^{\mathrm{TM}}$ DS was able to traverse the biliary anastomosis in all patients that have had stricture resolution, but in only one who had failed endoscopic treatment.

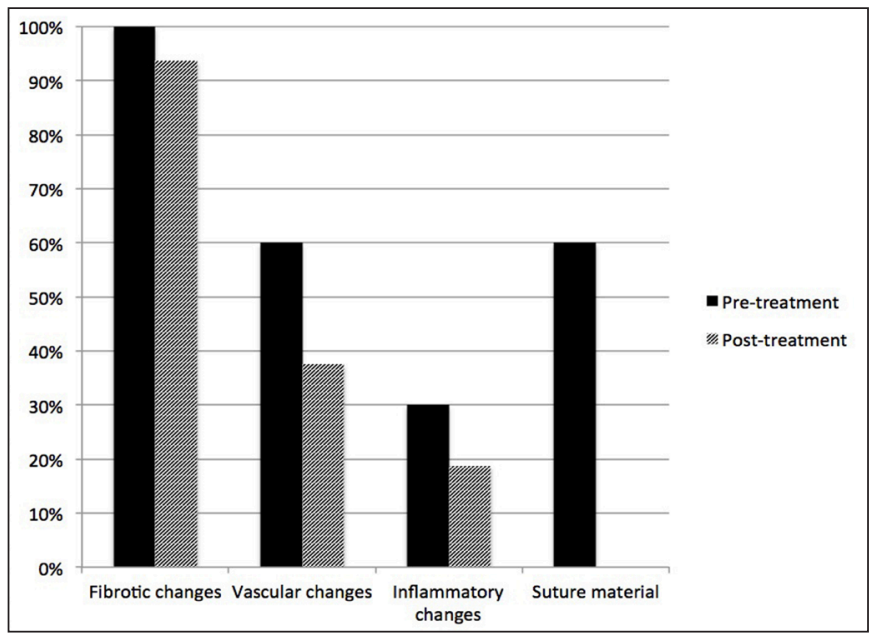

FIGURE 5. Comparison of cholangioscopic findings' prevalence before and after endoscopic treatment for biliary anastomotic stricture.

None of the cholangioscopic findings or the need of SOC to traverse the AS were statistically correlated to treatment outcome or stricture recurrence.

\section{DISCUSSION}

In the post liver transplant scenario, single operator cholangioscopy using SpyGlass ${ }^{\mathrm{TM}}$ DS system has been used to assist guide wire placement through severe anastomotic strictures in both deceased donor and $\operatorname{LDLT}^{(11-13,15,17,18,20,24)}$. Analyzing all data together, SOC is a valuable option to establish access across biliary anastomotic strictures that could not have been granted under fluoroscopic view. It is not only less invasive than other options available, such as percutaneous trans-hepatic drainage or surgery, but also it has been shown to be less expensive ${ }^{(18)}$. Nevertheless, more studies are necessary to consolidate the data.

Cholangioscopy has also been described in the management of biliary cast syndrome ${ }^{(14)}$ and to guide steroid injection after stricture dilation $^{(25)}$.

Nonetheless, there are very few studies describing cholangioscopic findings in post LT patients and to our knowledge no paper has been published addressing the cholangioscopic evaluation after endoscopic treatment with FCSEMS.

One of the earliest reports of post LT choledochoscopy date from 1999. Siddique et al. reported their experience with motherbaby scopes in the diagnosis and management of biliary tract diseases in general. There were 14 patients with anastomotic biliary strictures; ulceration and severe inflammatory changes were seen in $8(57.1 \%)$, whereas cicatricial strictures and mild inflammatory changes in $4(28.5 \%)$ individuals. Two patients suspected to have AS had actually been misdiagnosed, once obstruction was disclosed as a mixture of suture material and stone debris. Choledochoscopic was necessary to assist guide wire passage through the stricture in $4(28.5 \%)$ cases. Brushing obtained during the procedure revealed cytomegalovirus inclusions in 2 and fungal elements in $1^{(16)}$. Our experience with SOC corroborates in great part with their results. Except for a discrepancy in the prevalence of cicatricial changes, most of the data matches. The median time between LT and ERCP in our study was 159 days but it was not informed in theirs; a difference in this time interval could explain the higher number of fibrotic changes in our casuistic. Moreover, authors have also witnessed the misinterpretation of suture material mixed to sludge, peculiar in this group of patients and which diagnose is not possible without direct visualization. The use of cholangioscopy to assist guide wire passage through severe stricture was proven efficient whenever necessary ${ }^{(16)}$.

As in our study, Hoffman et al. identified fibrotic changes in $100 \%$ of post-LT biliary anastomotic strictures evaluated. The authors described the feasibility and outcome analysis of mother-baby methylene blue-aided cholangioscopy in patients with biliary strictures. They evaluated 7 post-LT AS, describing all of them as a smooth and pale mucosa without inflammatory changes. Staining with methylene blue was not uptake indicating the presence of a scar tissue ${ }^{(10)}$.

The visual appearance described by Siddique et al. ${ }^{(16)}$ was confirmed in the study published by Balderrano et al. ${ }^{(19)}$. The authors presented a prospective evaluation of SOC in post LT biliary disorders. Twelve of them had AS and they described two different patterns observed during cholangioscopy: one included the presence of mild erythema and scaring of the AS with non-remarkable histological findings (9/12) and the second consisted in the presence of severe edema, erythema, ulceration with sloughing at the stricture level with histological examination compatible with of acute cholangitis (3/12). Patients with scaring and erythema had better results with endoscopic treatment $(88.9 \%$ vs $33.4 \%, P=0.13)$ requiring fewer ERCP sessions $(2.7 \pm 1.2$ vs $5.3 \pm 2.5, P=0.03)$ and shorter stenting period $(167 \pm 87$ vs $457 \pm 257$, $P=0.01)^{(19)}$. Even though we have found similar prevalence of fibrotic changes and ulceration in our casuistic we were not able to demonstrate that cholangioscopic findings could predict the outcome after endoscopic therapy.

In our study, cholangioscopy was able to detect suture material that had not been previously identified at imaging exams or ERCP in 12 patients. Four of them were anchoring biliary sludge that had been misdiagnosed as stones at abdominal ultrasound. The most interesting fact was the disappearance of sutures after endoscopic stenting, observed in all cases, even in those who had the stent migrated. The consequences of surgical sutures' delayed absorption in this scenario are unknown, but in addition to the stenosis they could lead to more bile stasis and increase sludge formation. Concerning their disappearance, we could interrogate if the metal stent radial forces could contribute, but it is not fully understood at this point. It is also important to acknowledge the possible role of surgical sutures in the maintenance of biliary injury, following the example of metallic clips in bariatric surgery anastomotic complications. Because of our study's small number, we were not able to prove theses hypothesis.

A second version of SpyGlass ${ }^{\mathrm{TM}}$ DS II was launched after the study had been concluded. Although the new version has improved lighting and resolution, there is not sufficient data to predict impact of this new version in our setting of patients. 
In regard to the outcome of endoscopic treatment with FCSEMS, comparing the results of this current study to our previously published data on 6-month metal stent indwelling(2), we noticed initially contradictory results. It is important to state that we proposed to maintain the metal stent in place for 1-year in the present study based on the hypothesis that the high recurrence rate we had observed after FCSEMS in the previous study was due to the 6-month stent indwelling. As a result we noticed a higher migration rate $(66 \%$ vs $10 \%$ ) after 1-year metal stent indwelling, associated to lower stricture resolution ( $44.4 \%$ vs $83.3 \%$ ) as well as lower recurrence rate $(12.5 \%$ vs $32 \%)^{(2)}$. Considering that stricture recurrence occurred after a median follow-up of 4.9 months ${ }^{(2)}$ and correlating the data of both studies we may interrogate if at the present one, patients had the stricture resolved at some point between 6 and 12 months when, eventually, the stent could have migrated and then stricture recurrence was diagnosed at the scheduled ERCP for stent removal.

Cholangitis and pancreatitis are the two most frequent adverse events associated to ERCP in the post-LT population undergoing $\mathrm{SOC}^{(24)}$. In our study we performed cholangioscopy pre and post treatment and observed an overall mild acute pancreatitis rate of $10 \%$ ( 2 out of 20). Although this incidence is in accordance with previous literature ${ }^{(24)}$, after the second case of acute pancreatitis observed at pre-treatment ERCP we decided to review our protocol and included rectal indomethacin as a preventive measure. Concurrently we adopted prophylactic antibiotics to preclude cholangitis. There were no adverse events from this point on.

Some limitations in this study should be pointed: this is a single center trial with a small number of patients, which may compromise statistical analysis. A multivariate analysis could not be performed. A larger prospective, multicenter trial with a greater number of patients could evaluate predetermined criteria as an attempt to identify if any cholangioscopic finding could predict endoscopic treatment outcome.

In conclusion, ERCP with SOC is feasible and safe in post DLT patients with biliary anastomotic strictures. Cholangioscopic findings can be classified into fibrotic, vascular and acute inflammatory changes. Cholangioscopy is an important tool to prevent ERCP failure due to the impossibility of negotiating guide wire passage through a tight stricture, but its overall role for diagnoses and treatment is this group of patients is not clearly defined.

\section{Authors' contribution}

Martins FP: study conception and design; analysis and interpretation of the data; drafting of the article. Seleti SMR, Contini ML: data acquisition. De Paulo GA: data acquisition; analysis and interpretation of the data. Ferrari AP: conception and design; critical revision of the article and final approval of the article.

\section{Orcid}

Fernanda Prata Martins: 0000-0002-7017-9910.

Silvia Mansur Reimão Seleti: 0000-0003-2286-0039.

Mônica Lucia Contini: 0000-0002-1532-787X.

Gustavo Andrade De Paulo: 0000-0002-7926-9373.

Angelo Paulo Ferrari: 0000-0002-7062-288X.

Martins FP, Seleti SMR, Contini ML, De Paulo GA, Ferrari AP. Há lugar para a avaliação colangioscópica na estenose biliar anastomótica pós-transplante hepático de doador cadáver? Arq Gastroenterol. 2020;57(4):347-53.

RESUMO - Contexto - As complicações biliares continuam sendo uma das principais causas de morbidade e perda do enxerto após o transplante hepático. O tratamento endoscópico das complicações biliares provou ser eficaz ao longo do tempo, deixando o tratamento cirúrgico restrito a casos de exceção. No entanto, ainda não podemos prever quais pacientes terão maior potencial de se beneficiar da terapia endoscópica. Objetivo - Nesta premissa, decidimos realizar este estudo para avaliar o papel e a segurança da colangioscopia peroral de operador único (CPO) no tratamento endoscópico das estenoses anastomóticas biliares (EA) pós-transplante hepático. Métodos - Entre março de 2016 e junho de 2017, 20 pacientes consecutivos encaminhados para tratamento endoscópico da EA biliar foram incluídos neste estudo prospectivo de coorte observacional. Os critérios de inclusão foram idade superior a 18 anos e um transplante hepático de doador falecido realizado há pelo menos 30 dias. Pacientes com estenose biliar não anastomótica, fístula biliar, "cast" síndrome, qualquer terapia endoscópica prévia, gravidez e incapacidade de fornecer consentimento informado foram excluídos. Todos os pacientes foram submetidos à CPO antes da terapia endoscópica com prótese metálica autoexpansível totalmente coberta (PMAEC) e após a sua remoção. Resultados - Na CPO realizada antes do tratamento endoscópico, o orifício de estenose e alterações fibróticas foram visualizadas em todos os pacientes, alterações vasculares e a presença de suturas cirúrgicas em $60 \%$, enquanto alterações inflamatórias agudas em $30 \%$. A CPO foi determinante para a transposição do fio-guia através da estenose em cinco casos. Uma PMAEC foi implantada com sucesso em todos os pacientes. A taxa de resolução da estenose foi de 44,4\% (tempo médio de permanência de 372 dias). A recorrência da EA foi de 12,5\% (acompanhamento médio de 543 dias). Os eventos adversos foram migração distal (66,6\%) e proximal (5,5\%) da prótese metálica, oclusão da PMAEC (16,6\%), dor abdominal intensa $(10 \%)$ e pancreatite aguda leve $(10 \%)$. A CPO foi repetida após a remoção da PMAEC. A colangioscopia realizada após o tratamento endoscópico mostrou alterações fibróticas em todos, exceto em um paciente; alterações vasculares e inflamatórias agudas foram menos frequentes em comparação à CPO inicial. O desaparecimento do material de sutura, observado em todos os casos, foi notável. Nenhum dos achados colangioscópicos foram estatisticamente correlacionados ao resultado do tratamento ou à recorrência de estenose. Conclusão - A colangioscopia peroral é viável nos pacientes pós-transplante hepático com estenose biliar anastomótica. Os achados colangioscópicos podem ser classificados em alterações inflamatórias agudas, fibróticas e vasculares. A colangioscopia pode ser útil para auxiliar na passagem do fio-guia, mas seu papel geral na mudança de tratamento nos pacientes pós-transplante hepático não foi demonstrado.

DESCRITORES - Transplante de fígado. Stents metálicos autoexpansíveis. Constrição patológica. Sistema biliar. 


\section{REFERENCES}

1. Associação Brasileira de Transplante de Órgãos. Dimensionamento dos Transplantes no Brasil e em cada estado (2011-2018). Registro Brasileiro de Transplantes, 2018. [Internet]. [Access 2019 September 17]. Available from: http://www.abto. org.br/abtov03/Upload/file/RBT/2018/Lv_RBT-2018.pdf.

2. Martins FP, De Paulo GA, Contini MLC, Ferrari AP. Metal versus plastic stents for anastomotic biliary strictures after liver transplantation: a randomized controlled trial. Gastrointest Endosc. 2018;87:131.e1-131.e13.10.

3. Nakajima M, Akasaka Y, Fukumoto K, Mitsuyoshi Y, Kawai K. Peroral cholangiopancreatosocopy (PCPS) under duodenoscopic guidance. Am J Gastroenterol. 1976;66:241-7.

4. Chen YK, Pleskow DK. SpyGlass single-operator peroral cholangiopancreatoscopy system for the diagnosis and therapy of bile-duct disorders: a clinical feasibility study (with video). Gastrointest Endosc. 2007;65:832-41.

5. Lenze F, Bokemeyer A, Gross D, Nowacki T, Bettenworth D, Ullerich H. Safety, diagnostic accuracy and therapeutic efficacy of digital single-operator cholangioscopy. United European Gastroenterol J. 2018;6:902-9.

6. Chen YK, Parsi MA, Binmoeller KF, Hawes RH, Pleskow DK, Slivka A, et al. Single-operator cholangioscopy in patients requiring evaluation of bile duct disease or therapy of biliary stones (with videos). Gastrointest Endosc. 2011;74:805-14.

7. Maydeo A, Kwek BE, Bhandari S, Bapat M, Dhir V. Single-operator cholangioscopy-guided laser lithotripsy in patients with difficult biliary and pancreatic ductal stones (with videos). Gastrointest Endosc. 2011;74:1308-14.

8. Siddiqui AA, Mehendiratta V, Jackson W, Loren DE, Kowalski TE, Eloubeid MA. Identification of cholangiocarcinoma by using the Spyglass Spyscope system for peroral cholangioscopy and biopsy collection. Clin Gastroenterol Hepatol. 2012;10:466-71; quiz e48.

9. Laleman W, Verraes K, Van Steenbergen W, Cassiman D, Nevens F, Van der Merwe S, et al. Usefulness of the single-operator cholangioscopy system SpyGlass in biliary disease: a single-center prospective cohort study and aggregated review. Surg Endosc. 2017;31:2223-32.

10. Hoffman A, Kiesslich R, Bittinger F, Galle PR, Neurath MF. Methylene blue-aided cholangioscopy in patients with biliary strictures: feasibility and outcome analysis. Endoscopy. 2008;40:563-71.

11. Kumar S. Cholangioscopy-directed endoscopic intervention for post-liver transplantation anastomotic biliary stricture. Gastrointest Endosc. 2015;81:1014-5.

12. Parsi MA, Guardino J, Vargo JJ. Peroral cholangioscopy-guided stricture therapy in living donor liver transplantation. Liver Transpl. 2009;15:263-5.

13. Wright H, Sharma S, Gurakar A, Sebastian A, Kohli V, Jabbour N. Management of biliary stricture guided by the Spyglass Direct Visualization System in a liver transplant recipient: an innovative approach. Gastrointest Endosc. 2008;67:1201-3.
14. Navaneethan U, Venkatesh PG, Al Mohajer M, Gelrud A. Successful diagnosis and management of biliary cast syndrome in a liver transplant patient using single operator cholangioscopy. JOP. 2011;12:461-3.

15. Gürakar A, Wright H, Camci C, Jaboour N. The application of SpyScope ${ }^{\circledR}$ technology in evaluation of pre and post liver transplant biliary problems. Turk J Gastroenterol. 2010;21:428-32.

16. Siddique I, Galati J, Ankoma-Sey V, Wood RP, Ozaki C, Monsour H, et al. The role of choledochoscopy in the diagnosis and management of biliary tract diseases. Gastrointest Endosc. 1999:50:67-73.

17. Woo YS, Lee JK, Noh DH, Park JK, Lee KH, Lee KT. SpyGlass cholangioscopy-assisted guidewire placement for post-LDLT biliary strictures: a case series. Surg Endosc. 2016;30:3897-903.

18. Martins FP, Ferrari AP. Cholangioscopy-assisted guidewire placement in post-liver transplant anastomotic biliary stricture: efficient and potentially also cost-effective. Endoscopy. 2017;49:E283-E284.

19. Balderramo D, Sendino O, Miquel R, de Miguel CR, Bordas JM, Martinez-Palli $\mathrm{G}$, et al. Prospective evaluation of single-operator peroral cholangioscopy in liver transplant recipients requiring an evaluation of the biliary tract. Liver Transpl. 2013;19:199-206

20. Hüsing-Kabar A, Heinzow HS, Schmidt HH, Stenger C, Gerth HU, Pohlen M, et al. Single-operator cholangioscopy for biliary complications in liver transplant recipients. World J Gastroenterol. 2017;23:4064-71.

21. Inamdar S, Han D, Passi M, Sejpal DV, Trindade AJ. Rectal indomethacin is protective against post-ERCP pancreatitis in high-risk patients but not average-risk patients: a systematic review and meta-analysis. Gastrointest Endosc. 2017;85:67-75

22. Othman MO, Guerrero R, Elhanafi S, Davis B, Hernandez J, Houle J, et al. A prospective study of the risk of bacteremia in directed cholangioscopic examination of the common bile duct. Gastrointest Endosc. 2016;83:151-7.

23. Cotton PB, Lehman G, Vennes J, Geenen JE, Russell RC, Meyers WC, et al. Endoscopic sphincterotomy complications and their management: an attempt at consensus. Gastrointest Endosc. 1991;37:383-93.

24. Bokemeyer A, Gross D, Brückner M, Nowacki T, Bettenworth D, Schmidt H, et al. Digital single-operator cholangioscopy: a useful tool for selective guidewire placements across complex biliary strictures. Surg Endosc. 2019;33:731-7.

25. Franzini T, Moura R, Rodela G, Andraus W, Herman P, D'Albuquerque L, et al. A novel approach in benign biliary stricture - balloon dilation combined with cholangioscopy-guided steroid injection. Endoscopy. 2015;47 (Suppl 1): E571-2. 